anales de psicología / annals of psychology

2020, vol. 36, $\mathrm{n}^{\circ} 1$ (january), 143-154

https://doi.org/10.6018/analesps.370661
(C) Copyright 2020: Editum. Servicio de Publicaciones de la Universidad de Murcia. Murcia (Spain) ISSN print edition: 0212-9728. ISSN on line edition (http://revistas.um.es/analesps): 1695-2294.

On line edition License Creative Commons 4.0: BY-NC-ND

\title{
Development and validation of the Teaching Styles Inventory for Higher Education (TSIHE)
}

\author{
Diana Abelloํㅜ Jesús Alonso-Tapia ${ }^{2}$, and Ernesto Panadero ${ }^{3}$
}

1 Departamento de psicopedagogia, Facultad de Educación, Universidad Pedagógica Nacional (Colombia) 2 Departamento de psicología clínica y de la salud, Facultad de psicologia, Universidad Autónoma de Madrid (Spain) 3 Departamento de psicología evolutiva y de la educación, Facultad de Psicología, Universidad Autónoma de Madrid (Spain)

\begin{abstract}
Título: Desarrollo y validación del Inventario de Estilos de Enseñanza para Educación Superior (IEE).

Resumen: El Estilo de enseñanza se entiende como la forma particular de enseñar del docente, influyendo en la motivación, el aprendizaje y el rendimiento. El articulo presenta el estudio sobre las fuentes de validez estructural del Inventario de estilo de enseñanza para educación superior (IEE). Participaron 3312 estudiantes universitarios. Los datos se analizaron mediante técnicas confirmatorias para determinar el ajuste de su estructura de cuatro modelos alternativos. Para el análisis, la muestra fue dividida de forma aleatoria en ocho submuestras. Los análisis principales se llevaron a cabo con la primera y posteriormente se realizó un análisis de validación cruzada con los distintos subgrupos. El modelo 4, bifactor, es el que presentó los mejores índices de ajuste $\left(\chi^{2}=782.75, d f=322, p<.001, \chi^{2} / d f=2.44, T L I=\right.$ $.98, C F I=.98, R M S E A=.058)$. Las escalas mostraron también muy buenos índices de fiabilidad. El cuestionario evalúa un factor general bipolar el estilo de enseñanza- $(\omega=.99)$, y cuatro dimensiones también bipolares: in teracción profesor-alumno $(\omega=.97)$, negociación en la toma de decisiones $(\omega=.96)$, estructuración de la enseñanza $(\omega=.96)$ y control del comportamiento $(\omega=.96)$. Se concluye que el cuestionario, reúne los requisitos para ser utilizado con fines aplicados y de investigación.

Palabras clave: Estilo de enseñanza; Interacción profesor-alumno; Estructuración de la enseñanza; Control del comportamiento; Educación superior.
\end{abstract}

\section{Introduction}

The relationship between teachers' instructional style, interactions with students and learning environment has been investigated in a range of studies (Beyhan, 2018). Research shows that the instructional style in which a teacher approaches the classroom influences students' motivation to learn, academic performance, satisfaction and involvement (Frunzâ, 2014). Within this framework, the construct of teaching style emerges, conceptualized as the specific approach in which a teacher structures his/her class and lectures (Camargo, 2010; Camargo \& Hederich, 2007). Given the effect of teaching style on academic performance, this construct can contribute to design successful intervention programs.

Therefore, it is relevant to evaluate the teaching style as it describes teachers' classroom instructional actions. One instrument with such purpose is the Teaching Styles Inventory for Higher Education (TSIHE) (Abello, Hernandez \& Hederich, 2012). Among its advantages are that (a) its con-

* Correspondence address [Dirección para correspondencia]:

Diana M. Abello. Departamento de psicopedagogía, Facultad de Educación, Universidad Pedagógica Nacional (Colombia). Calle 72 No. 11-86, Bogotá, Colombia. Código Postal: 110221

E-mail: dabello@pedagogica.edu.co

(Article received: 30-3-2019; revised: 6-6-2019; accepted: 12-9-2019)
Abstract: Teaching style is conceptualized as the teacher's specific instructional approach that influences students' motivation, learning, and performance. The main aim of this study is to explore the sources of structural validity of the of the Teaching Styles Inventory for Higher Education (TSIHE) using confirmatory techniques. A total of 3312 university students participated in the study. Data were analyzed using confirmatory techniques to find the adjustment of their structure to four alternative models. For the analyses, data were randomly divided into eight subgroups. The first subgroup was employed to test the goodness of fit of the tested model. Subsequently, a cross-validation analysis was performed with the eight subgroups. The bifactor model showed the best fit indexes: $\left(\chi^{2}=\right.$ $782.75, d f=322, p<.001, \chi 2 / d f=2.44, T L I=.98, C F I=.98, \operatorname{RMSE} A=$ $.058)$. Its scales also present high reliability values. The questionnaire assesses a bipolar general factor, the teaching style, $(\omega=.99)$, and four dimensions, also bipolar: teacher-student interaction $(\omega=.97)$, decision-making negotiation $(\omega=.96)$, teaching structuring $(\omega=.96)$ and behavioral control $(\omega=.96)$. It was concluded that the questionnaire presents appropriate psychometrical properties to use for research and practical purposes.

Keywords: Teaching style; Teacher-student interaction; Teaching structuring; Behavioral control; Higher Education.

struction is grounded on pedagogical principles, acknowledging teaching as a separate phenomenon from learning with its own dynamics; (b) it is based on the students' perception on the frequency teachers' behaviors during the class, beyond self-report and decreasing the response bias; and (c) its reliability has already been explored and proven. The aim of this study is to continue the TSIHE development and validation, conducting advanced psychometric analyses (i.e. confirmatory factor analysis) to identify whether the data gathered through the instrument adjust to the TSIHE model.

\section{Teaching Style}

The construct of teaching style was introduced by Fischer \& Fischer (1968). According to this construct, teachers employ different instructional approaches that structure the classroom groups and their relationships with the students. Over the years, different ways of understanding the construct arose. Bennett (1979) reviewed several teaching style typologies, and concluded that those typologies ignored intermediate styles, reducing the classifications to a few dimensions of behavior and coming closer to aspects related to educational assessment. Bennet asserted that the studies conducted at that time presented flaws on their methodological rigor and that most of them employ non-representative samples. Therefore, Bennet began to study with greater rigor the 
influence of teaching style on students' learning processes, although his studies had also been criticized methodologically.

In a more recent review, Camargo \& Hederich (2007) analyzed the teaching styles theories and proposed to group them in two traditions: the psychological and the pedagogical. The psychological tradition includes those proposals deriving from learning and cognitive styles. Theories in this tradition consider that the teaching style is a product of the teacher's own cognitive and learning approaches, based on the premise that the teacher teaches as he has learned. On the other hand, the pedagogical tradition includes theories that explain teaching style as the result of the teacher's pedagogical conceptions.

From the psychological tradition (Evans, 2004), the teaching styles adjustability is low and linked to the acknowledgement and transformation of the teacher's own cognitive and learning approaches. Consequently, the intervention focuses on identifying which are the best combinations between teacher and student. According to this perspective the ideal alignment implies the confluence of teachers and students with the same learning or cognitive style. On the other hand, theories framed in the pedagogical tradition (Brostrom, 1975) consider that style adjustability can occur based on the acknowledgement of the teacher's beliefs and conceptions, followed by educational processes focused on pedagogical models identified as ideal.

Regarding the measurement of the teaching styles, it is possible to observe tensions between both traditions. Though both use self-reported questionnaires, in the psychological tradition the goal is to identify the teachers' preferences and actions in the classroom, while in the pedagogical tradition the goal focus in determining the teachers' pedagogical beliefs and conceptions (Evans, 2004).

The tensions between both traditions are unsolvable if teaching style is conceptualized as a unidimensional construct. However, such tensions can be solved if a multidimensional structure is adopted. This is the proposal from the model by Abello \& Hernández (2010), which is multidimensional and based on a systemic understanding of the construct integrating aspects from both traditions. In this model, teaching style is understood as the teacher's behavioral expression in the classroom which is the result of personal fac- tors, such as their own educational history, and the interactions with students. Importantly, during these interactions, the teacher's underlying pedagogical conceptions influence the actions s/he performs. These conceptions are not usually at the forefront of the teacher's decision making, but they direct the instructional actions taken by the teachers (Pajares, 1992). Therefore, both need to be considered and explored.

\section{Measuring Teaching Style}

Next, we analyze the two most used teaching style questionnaires. First, the Teaching Styles Inventory (TSI) developed by Grasha (1996) comprises 40 items, which are answered on a seven-points Likert scale (agreement to disagreement). Initial validation studies showed that the instrument barely reaches acceptable levels of reliability for its five scales each representing a different teaching style (.62 to .65). Gafoor and Babu (2016) developed a new questionnaire based on the five styles established by Grasha for secondary education teachers in India. This questionnaire comprises 15 forced-answer items, each one with five options that the teacher must prioritize according to their preference. The five scales are above reliability standards (.82 to .98). Subsequently, Beyhan (2018) has employed the same questionnaire, but the reliability of the scales is lower (.75 to .83). Both studies present problems because the procedure used for the reliability analysis (Cronbach's alpha) is inadequate, since it is applied to ipsative scores (Chan, 2003).

A second instrument to measure teaching style arises within the Ibero-American context: The Teaching Styles Questionnaire (TSQ) elaborated by Martínez (2009). This questionnaire was based on the learning styles model of Alonso, Gallego, and Honey (1994), which proposes four learning styles: active, reflective, theoretical, and pragmatic. These authors posit that every student can have characteristics of the four styles, and that the effective novice obtains similar scores in the four, evidencing an ability to complete different types of tasks. Martinez's questionnaire posits teaching styles versus learning styles by asserting that a teaching style is shaped as a set of behaviors that favor one learning style. He proposes the relationships shown in Table 1. Importantly, learning styles are considered a learning myth and their research use is questioned (An \& Carr, 2017).

Table 1. Authors elaboration of teaching styles proposed by Martínez (2009).

Open (they raise new content, motivate the students with innovative activities about real problems, they
usually change their methodology).
Formal (they do not give contents that are not included in the program. encourage and value students' re-
flection, analysis).
Structured (they require objectivity in the answers and demand demonstrations based on theory).
Functional (they emphasize in practice and correct procedures)

This questionnaire facilitates the evaluation of four teaching styles (open, formal, structured and functional) through two bipolar scales Open/Formal and Structured/Functional, but the reliability values are low (.61 to .66). A more recent version of this instrument was proposed by Renes, Echeverry, Chiang, and Rangel (2013); some items in it are reworked and linguistic adjustments are made for the Chilean context, and they subsequently conduct a content validation employ- 
ing the Delphi method (Chiang, Diaz, Amer, \& MartinezGeijo, 2013).

However, some authors have argued that the operationalization of teaching style is unclear, and the development of instruments to measure it is scarce (Camargo \& Hederich, 2007; Rendón, 2013). Although, learning style construct has been highly questionable as it lacks empirical evidence supporting its effect on academic performance (An \& Carr, 2017). Additionally, there is a response bias (Rosenman, Tennekoon, \& Hill, 2011) as these questionnaires are filled out by the teachers reflecting about their own behavior, instead of asking the students to report their teachers' teaching style. And finally, as just presented, some of the questionnaires have poor psychometric characteristics. With the purpose of overcoming the theoretical and measurement limitations above mentioned, the teaching styles model created by Abello and Hernández (2010) emerges, followed by the development of a measurement instrument: the Teaching Styles Inventory for Higher Education (TSIHE). The model is based on, both, the pedagogical and the psychological traditions, recognizing the classroom as a teaching scenario, and the didactic materials as the axis to interpret the teacher's actions. Importantly, this instrument overcomes the three limitations by previous questionnaires. First, it is not based on learning approaches theory having been developed under a pedagogical frame. Second, the students are the ones reporting teachers' instructional approach decreasing the response bias. And third, the reliability indicators obtained across all its scales is above 78 (Abello, Hernández, y Hederich, 2012)

Importantly, the TSIHE psychometric characteristics has only been tested at the exploratory level (Abello \& Hernández, 2010; Abello, Hernández, \& Hederich, 2012; Hernández \& Abello, 2013). It is then necessary to study whether the structure proposed is adequate through the use of confirmatory techniques, and this is the aim of the present study. However, it is necessary first to describe the proposed model.

\section{The Teaching Styles Inventory for Higher Educa- tion questionnaire}

The theoretical model elaborated by Abello and Hernández (2010) is based on a systemic understanding of the classroom dynamics applying the principles discussed by Bertalanffy (1976). According to this author, the classroom is as a set of interconnected members, students and teacher, that influence each other, creating a complex, changing and dynamic whole. In the classroom students and teacher bring their expectations, intentions and needs, and displays their characteristics. It is in the interactions that the teaching style emerges, as an expression of the teacher approach to solve the demands in classroom situations. The model structure includes two dimensions, one of them with its own three sub-dimensions, which characteristics are described below (also Table 2).

Table 2. Structure of the TSIHE.

\begin{tabular}{|c|c|c|c|}
\hline \multirow[t]{2}{*}{ Dimension } & \multirow[t]{2}{*}{ Sub-dimension } & \multicolumn{2}{|c|}{ Score } \\
\hline & & Low & High \\
\hline Social & Teacher-student interaction (T-SI) & Emotionally detached from students & Emotionally attached to students_ \\
\hline Clocsroom manooment & Teacbing structuring (TS) & $\begin{array}{l}\text { Flexible with classroom structure } \\
\text { and curriculum }\end{array}$ & $\begin{array}{l}\text { Rigid with classroom structure and } \\
\text { curriculum }\end{array}$ \\
\hline Classroom management & $\begin{array}{l}\text { Behavioural control (BC) } \\
\text { Decision-makino neootiation (D-MN)- }\end{array}$ & Lenient with inappropriate behaviour & $\begin{array}{l}\text { Strict with behaviour } \\
\text { Compromising with decisions }\end{array}$ \\
\hline
\end{tabular}

A) Social dimension. This dimension is evaluated through the Teacher-student Interaction Scale, that allows measuring the students' perceived level of emotional attachment to their teachers. A teacher's ability to be open and accessible to students is considered a highly influential variable since it is highly valued by students and seems to be related to the teacher's ability to adapt to different contexts. In this regard, Covarrubias and Piña (2004) indicated that university students consider it fundamental to their learning that a teacher exhibits accessibility and openness. Besides, these authors considered that even though it is positive that a teacher is accessible to students, he must not cross boundaries at to the point of losing his role. On the other hand, Grasha (1996), in his teaching style model, gives great weight to this dimension, which he refers to as interpersonal rapport, alluding to the teacher's ability to generate a psychological connection or empathy with the student, a fundamental aspect in any interper- sonal relationship.

B) Classroom management dimension. This dimension refers to the design and implementation in the classroom of effective routines, rules and procedures to perform pedagogic activities (Henderson, 2016). When teachers structure their teaching adequately but show a certain degree of flexibility and foster mutual respect, students tend to have a more positive perception of learning and more motivation (Evans, Harvey, Buckley, \& Yan, 2009; Henderson, 2016; Sowell, 2013). This dimension is evaluated through three sub-scales.

b1) Teaching structuring scale. It measures the student's perception of the course level structure describing the degree to which the student perceives regular teaching patterns in relation to handing in work, taking tests, monitoring the students' activity, and giving feedback. Diverse studies show that structured lessons seem to influence students' learning positively, 
in contrast to very flexible lessons (Antoniou \& Kalinogloua, 2013; Chang, 2010). Students perform better when the teacher sets rules to manage the teaching and learning process, provides feedback and listens to their needs as they make adjustments. However, when the teaching and learning process is too structured, it makes students anxious and, in some cases, it generates feelings of low competency and effectiveness. The importance of structuring work is also highlighted by Bandura (1991), who mentions that it is necessary to indicate the steps that can help people reach complex goals in a way that guides and regulates the efforts that otherwise could be misdirected. Zimmerman (2000) also underlines the importance of structuring work in relation to the self-regulation development process, which requires highly structured environments in the first three stages.

b2) Behavioral control scale. It measures the level at which teachers control their students' behavior during classroom time. In general, inappropriate classroom behaviors affect negatively student's perception of the classroom climate and impacts their learning (Simón \& Alonso-Tapia, 2016). Sowell (2013) employed the Behavioral and Instructional Management Scale (BIMS) with primary students identifying three categories: a) interventionist: teacher impose direct consequences for students inappropriate behavior; b) non-interventionist: this teacher takes preventive-type actions, creating an emotionally and psychologically positive classroom environment; and c) interactionist: this teacher combines both reactive and preventive elements. The study shows that students of teachers with an interactionist style have a greater level of academic achievement than those with an interventionist style.

Although there are only a few studies on this topic in higher education, Henderson (2016) asserted that students' inappropriate class behavior affects the group's learning because the teacher must put the lecture aside to generate corrective actions or warnings, and these interruptions take up class time. This author concluded that it is necessary to provide teaching staff with tools to improve their behavioral control strategies in the classroom.

b3) Decision-making negotiation scale. It measures the level at which a teacher negotiates the classroom rules and decisions with the students. Decision-making influences students' perception of their capacity to influence what happens in the classroom. It combines the classroom management style (Henderson, 2016 y Sowell, 2013) and the leadership style theory's (Hersey y Blanchard; 1969). A teacher that negotiates decision-making with the students by making them participants in rulemaking is considered the most beneficial for students' learning (Simón \& Alonso-Tapia, 2016; Sowell, 2013). Regarding academic decisions- i.e. topics that will be covered, course methodology or evaluation-, research suggests that when the students feel they can choose and make decisions, their satisfaction with the course increases along with their ability to self-regulate (Alonso-Tapia, 1997; Panadero \& Alonso-Tapia, 2014). However, it is necessary to point out that the decision-making process must be controlled since, if the teacher gives too much responsibility to the students, it could make them anxious if they feel they do not have clear guidance (Grasha, 1996).

\section{Aim and Hypotheses}

Considering the four scales of the Teaching Styles Inventory for Higher Education (TSIHE) and the structure proposed by the authors in earlier studies (Abello \& Hernández, 2010; Abello, Hernandez \& Hederich, 2012; Hernández \& Abello 2013), the main aim of this study is to explore the sources of structural validity of the questionnaire using confirmatory techniques. First, it was tested a model with four factors correlated between them, but without grouping them in any dimension, as correlations between factors are the base of any other model. Then, on the base of the correlations found, it was tested a second model suggested by previous studies, with four factors grouped in two dimensions social interaction and academic management-. However, it existed also the possibility that all the factors correlated high enough to reflect the existence of only one dimension defining the construct "teaching style". So, a third model with four factors grouped in one dimension was also tested. Besides, it was also possible that data were best explained by a bifactor model, in which the variance explained be the general factor "teaching style" without being necessarily consider a second order factor. Therefore, a bifactor model was also tested. Our main hypothesis was that all models would fit, but we have no hypothesis about which one would have the best fit.

\section{Method}

\section{Participants}

A total of 3312 university students from the National Pedagogic University of Colombia participated. The sampling was conducted ensuring representativeness of all the faculties of the participant university: Fine Arts, Science, and Technology, Education, Physical Education, and Humanities. From the sample, $59.5 \%$ were women and $40.5 \%$ were men. Age range ran from - 16 to 51 years old ( $M: 21.28)$. The students were selected according to their year level: first year $=35.8 \%$, second year $=16.2 \%$, third year $=21.1 \%$, fourth year $=19.2 \%$, fifth year $=7 \%$. Regarding the socioeconomic background, $63.7 \%$ of the students come from a low, the $31.7 \%$ from a medium and only 4.6 from high background. The whole sample was randomly divided into eight 
subgroups of approximately equal size to avoid the effect of such a large sample on the values of $\chi^{2}$. That subgroups let us perform multi-group cross-validation analyses for testing invariance by group.

\section{Materials}

Teaching Styles Inventory for Higher Education (TSIHE) (Hernandez \& Abello, 2013). The inventory initially included 31 items, scored on a 4-point Likert scale, from 1 (completely agree) to 4 (completely disagree). Items were grouped in four scales corresponding to two dimensions: (1) Social: Teacherstudent interaction; and (2) Classroom management: (2a) Teaching structuring, (2b) Behavioral control and (2c) Decision-making negotiation. After the initial exploratory analyses conducted in previous studies, the questionnaire was reduced to 28 items for this study (Appendix 1).

\section{Procedure}

Student and teacher participation was voluntary and data were handled to ensure anonymity. Data were collected in the students' classrooms. Students were asked to answer considering that the particular course they were attending at that precise moment. The TSIHE was applied in the last third of the academic period, to ensure that students had enough information about the teacher and the subject to be able to accurately complete the questionnaire. The application took an average of 35 minutes. The procedure was previously endorsed by the Research Center of the National Pedagogic University of Colombia and fulfilled the ethics requirements.

\section{Data Analysis}

To explore the questionnaire sources of structural validity, four different models were calculated and compared through confirmatory factor analysis using the first subsample. Once determined the model with best fit according to empirical evidence, a cross validation analysis of it was also carried out to test for measurement invariance between groups. After that, the reliability of its different scales was analyzed and descriptive statistics were calculated. Regarding missing data, participants missing over $5 \%$ were excluded. The rest of missing data were replaced by an item central score. The estimation method used was WLSMV, as data came from ordered categorical scales. The criteria described by Hair, and Black, Black, Babin \& Anderson, (2010) were adopted to accept or reject the model based on goodness of fit $(\chi 2 / g l<5$; TLI and CFI $>$.90; RMSE $A<.08)$. For the cross-validation analyses, the same estimation method and the same acceptance criteria were used. The MPLUS v.7 program was employed to run the analyses (Muthén \& Muthén, 1998-2012).

\section{Results}

\section{Factor Analyses}

CFA of Model 1. Table 3 shows the fit statistics of the confirmatory model, and Figure 1, the standardized estimates. All the estimated factor loadings $(\lambda)$ were significant $(p$ $<.001)$, as well as the proposed structural relations, all of which were also significant. Chi-square was significant, probably due to sample size, but the remaining fit indices were well within the values commonly used to accept a model. Consequently, the model is properly estimated and can be accepted. As correlation between factors were high, it was decided to go on testing models 2, 3 and 4 .

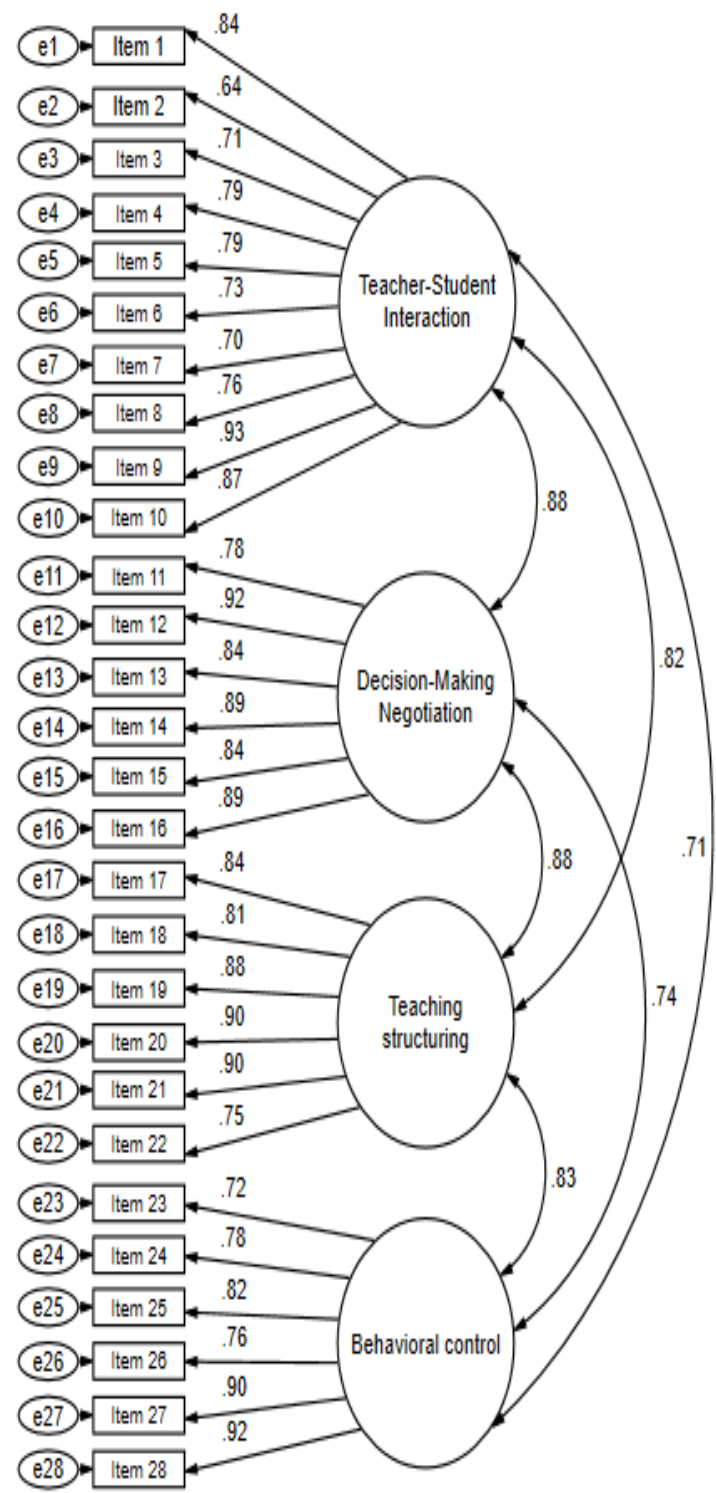

Figure 1. Model 1: Standardized measurement and structural weights. 
Table 3. Goodness of fit statistics for confirmatory factor analyses, and for multi-group cross-validation analysis.

\begin{tabular}{lccccccc}
\hline & $\chi^{2}$ & $d f$ & $P$ & $\chi^{2} / d f$ & TLI & CFI & RMSE $A$ \\
\hline M1 N=437 & 1233.45 & 344 & $<.001$ & 3.58 & .97 & .96 & .079 [CI: $\left..074, .083^{*}\right]$ \\
M2 $N=437$ & 1284.13 & 346 & $<.001$ & 3.71 & .96 & .96 & .076 [CI: $\left..072, .081^{*}\right]$ \\
M3 N=437 & 1284.13 & 346 & $<.001$ & 3.71 & .96 & .96 & .079 [CI: $\left..074, .083^{*}\right]$ \\
M3 N=437 & 787.75 & 322 & $<.001$ & 2.44 & .98 & .98 & .058 [CI: $.052, .063 *]$ \\
M4 MG & 7119.99 & 3290 & $<.001$ & 2.16 & .98 & .98 & .053 [CI: $\left..051, .055^{*}\right]$ \\
\hline
\end{tabular}

Notes: M: model; $N$ : number of subjects; MG: multi-group cross-validation analysis with eight groups. $N$ for each group: G1 = 437; G2 = 408; G3 = 422; $\mathrm{G} 4=399 ; \mathrm{G} 5=414 ; \mathrm{G} 6=393 ; \mathrm{G} 7=431 ; \mathrm{G} 8=408$.

CFAs of Model 2. Figure 2 shows the standardized estimates, and Table 3 , the fit statistics of the confirmatory model. All the estimated factor loadings $(\lambda)$ were significant $(p<.001)$, as well as the proposed structural relations, all of which were also significant. As for model fit, as can be seen in Table $3, \chi^{2}$ is significant, but the remaining fit indexes were well within the values commonly used to accept a model. Fit indexes of Model 2 have a bit worse but practically the same than those of Model 1.

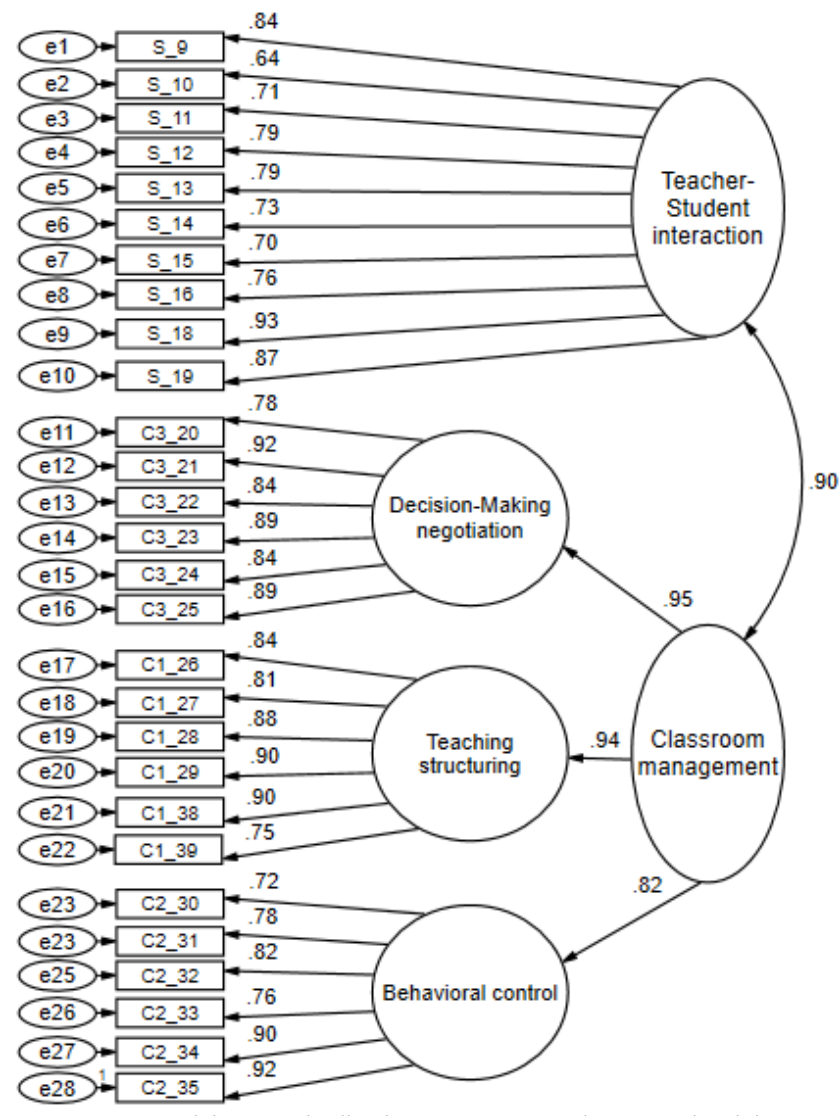

Figure 2. Model 2: Standardized measurement and structural weights.

CFA of Model 3. Figure 3 shows the standardized estimates, and Table 3 , the fit statistics of the confirmatory model. All the estimated factor loadings $(\lambda)$ were significant $(p<.001)$, as well as the proposed structural relations, all of which were also significant. As can be seen, $\chi^{2}$ is significant, but the remaining fit indexes, were well within the values commonly used to accept a model. The fact that goodness of fit is practically identical among the three models suggests that all of them are equally acceptable.

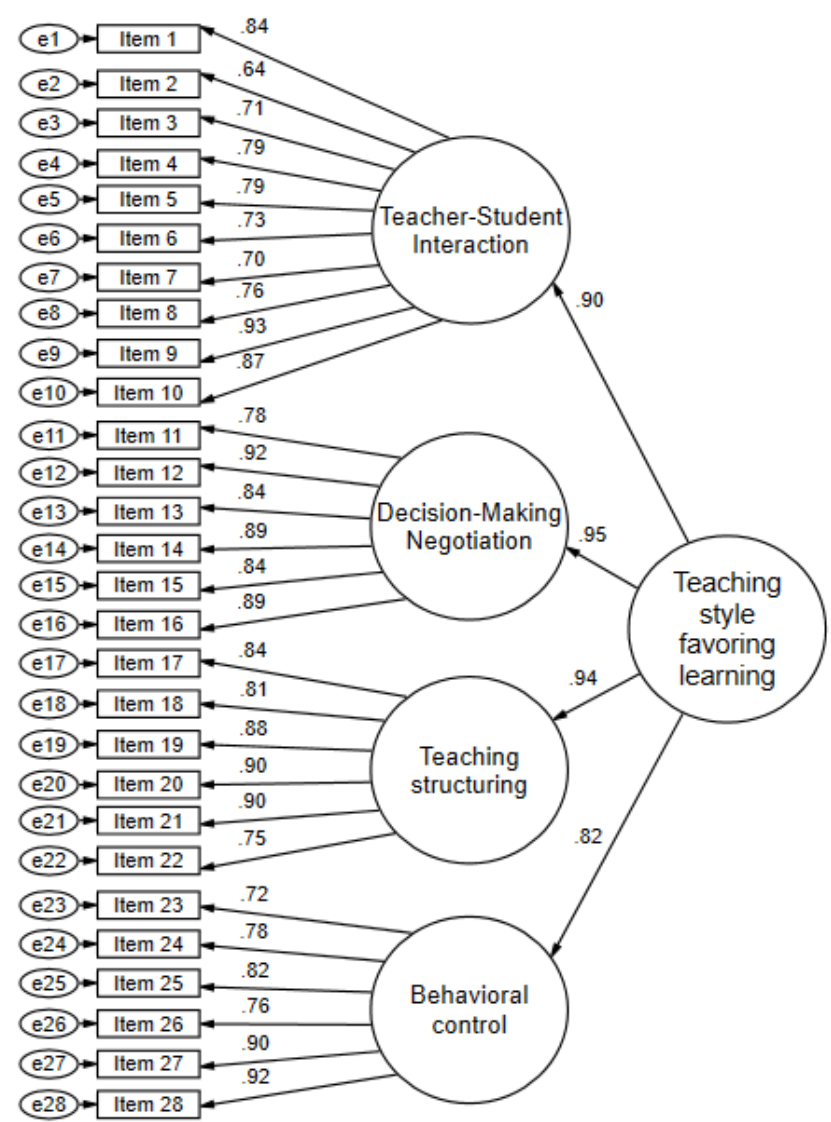

Figure 3. Model 3: Standardized measurement and structural weights.

CFA of Model 4. Figure 4 shows the standardized estimates, and Table 3, the fit statistics of the confirmatory model. All the estimated factor loadings $(\lambda)$ were significant $(p<.001)$, as well as the proposed structural relations, all of which were also significant. As can be seen, $\chi^{2}$ is significant, but the remaining fit indexes were well within the values commonly used to accept a model. As can be seen, fit indexes for Model 4 are slightly better that those for the remaining models. Therefore, a cross-validation analysis of this model was carried out. Its fit indexes are also included in Table 3. They fell also well within the standards limits of acceptance. In addition, fit indexes do not decline even if restrictions are imposed on the equality of parameters. 


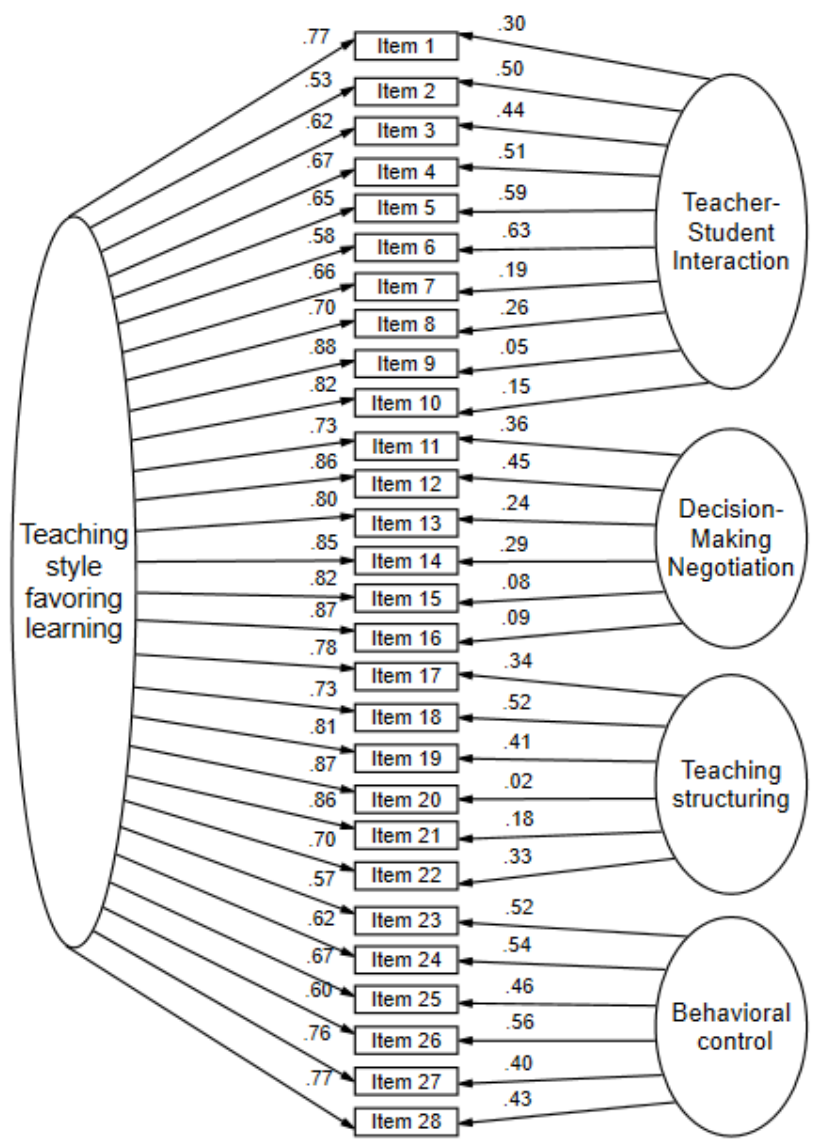

Note: Error indicators have been omitted for the sake of clarity of display.

Figure 4. Bifactor model: Standardized measurement and structural weights.

\section{Reliability and descriptive analysis}

The questionnaire general and specific scales are very reliable according to McDonald's $\omega$ indexes (1999). These were: teacher-student interaction: $\omega=.97$; decision-making negotiation: $\omega=.96$; teaching structuring: $\omega=.96$; and, behavioral control: $\omega=.96$. All of them are well above the standard level of acceptance. Descriptive statistics of item and scales are included in Table 4, and Correlation matrix between items in Table 5 .
Table 4. Means and standard deviations of items and scales.

\begin{tabular}{lcccccc}
\hline Items & $M$ & $S D$ & & Items \& scales & $M$ & $S D$ \\
\cline { 1 - 4 } TSI1 & 2.49 & 1.05 & & TS1 & 2.58 & 1.14 \\
TSI2 & 2.48 & 1.01 & & TS2 & 2.55 & 1.03 \\
TSI3 & 2.51 & 1.03 & & TS3 & 2.59 & 1.12 \\
TSI4 & 2.50 & 1.03 & & TS4 & 2.57 & 1.06 \\
TSI5 & 2.50 & 1.03 & & TS5 & 2.60 & 1.14 \\
TSI6 & 2.53 & .97 & TS6 & 2.57 & 1.09 \\
TSI7 & 2.56 & 1.01 & BC1 & 2.50 & .95 \\
TSI8 & 2.58 & 1.10 & BC2 & 2.53 & .99 \\
TSI9 & 2.56 & 1.29 & BC3 & 2.52 & .95 \\
TSI10 & 2.55 & 1.01 & BC4 & 2.55 & .99 \\
DMN1 & 2.55 & 1.07 & BC5 & 2.56 & 1.10 \\
DMN2 & 2.56 & 1.20 & BC6 & 2.56 & 1.11 \\
DMN3 & 2.53 & 1.20 & TSI & 25.26 & 8.19 \\
DMN4 & 2.58 & 1.13 & DMN & 15.32 & 5.71 \\
DMN5 & 2.55 & 1.00 & TS & 15.46 & 5.50 \\
DMN6 & 2.55 & 1.10 & BC & 15.22 & 4.97 \\
& & & Teaching Style & 71.26 & 21.94
\end{tabular}

1 TSI: Teacher-student interaction; DMN: Decision-making negotiation; TS: Teaching structuring; BC: Behavior control.

\section{Discussion}

The aim of this study was to study the factorial structure of the TSIHE on the base of the model posited by Hernandez y Abello (2013). Due to initial results, alternative models were tested. A bifactor model, with a general factor and four specific factors, was the one showing the best fit. The model was properly estimated, both in the confirmatory factor analyses and in the multi-group analysis. Additionally, each one of the four scales presented above the standards reliability. Taken together, these results allow asserting that the TSIHE is a valid and reliable instrument to measure teaching styles in higher education contexts. Finally, our questionnaire is not based in learning approaches theory, the students are the ones providing with the information reducing self-report bias from the teacher.

One of our key findings relates to the bifactor model. According to this model, even if there are specific factors that characterize the teaching style, the students perceive their teachers mainly in a holistic way. The same conclusion conveyed by the hierarchical model, the second with best fit. This implies that, in order to change the students' holistic perception in a significant way, their teachers should probably change most of the instructional patterns configuring the teaching style. It might be also possible that, given the correlation among the specific factors, a significant change in one of them will produce significant changes in the teaching style perception. Therefore, these alternative possibilities should be tested in future studies. On one side, interventions aimed at helping teachers to change, should be comprehensive including all the elements of the model. On the other, interventions could address a factor each time. Our hypothesis is that, if interventions address only one factor, change in the instructional approach will probably be insufficient to produce a change in the students' perceptions. In any case, our results have a clear implication: pre-service and in-service 
teachers need to receive training on how to adopt a teaching style beneficial for the classroom learning climate (AlonsoTapia \& Fernández-Heredia, 2009). It is then needed to de- velop teacher career development programs that provide training in this particular topic.

Table 5. Correlation matrix between items.

\begin{tabular}{|c|c|c|c|c|c|c|c|c|c|c|c|c|c|c|c|c|c|c|c|c|c|c|c|c|c|c|}
\hline 1 & 2 & 3 & 4 & 5 & 6 & 7 & 8 & 9 & 10 & 11 & 12 & 13 & 14 & 15 & 16 & 17 & 18 & 19 & 20 & 21 & 22 & 23 & 24 & 25 & 26 & 27 \\
\hline \multicolumn{27}{|c|}{$\overline{1}$} \\
\hline 2.593 & & & & & & & & & & & & & & & & & & & & & & & & & & \\
\hline 3.641 & .597 & & & & & & & & & & & & & & & & & & & & & & & & & \\
\hline 4.662 & .666 & .708 & & & & & & & & & & & & & & & & & & & & & & & & \\
\hline 5.676 & .643 & .656 & .774 & & & & & & & & & & & & & & & & & & & & & & & \\
\hline 6.620 & .625 & .608 & .687 & .818 & & & & & & & & & & & & & & & & & & & & & & \\
\hline 7.602 & .475 & .544 & .568 & .596 & .579 & & & & & & & & & & & & & & & & & & & & & \\
\hline 8.622 & .474 & .569 & .592 & .618 & .573 & .561 & & & & & & & & & & & & & & & & & & & & \\
\hline 9.711 & .493 & .557 & .620 & .673 & .609 & .626 & .618 & & & & & & & & & & & & & & & & & & & \\
\hline 10.676 & .516 & .597 & .649 & .680 & .622 & .661 & .620 & .774 & & & & & & & & & & & & & & & & & & \\
\hline 11.610 & .475 & .555 & .569 & .610 & .548 & .566 & .577 & .675 & .654 & & & & & & & & & & & & & & & & & \\
\hline 12.715 & .504 & .609 & .634 & .657 & .578 & .611 & .665 & .786 & .723 & .791 & & & & & & & & & & & & & & & & \\
\hline 13.668 & .430 & .544 & .561 & .588 & .521 & .562 & .607 & .742 & .659 & .670 & .799 & & & & & & & & & & & & & & & \\
\hline 14.706 & .450 & .567 & .606 & .630 & .548 & .596 & .631 & .780 & .697 & .679 & .814 & .792 & & & & & & & & & & & & & & \\
\hline 15.640 & .442 & .577 & .587 & .622 & .540 & .566 & .606 & .660 & .667 & .623 & .715 & .640 & .725 & & & & & & & & & & & & & \\
\hline 16.706 & .492 & .588 & .622 & .671 & .589 & 619 & .642 & .774 & .745 & .697 & .803 & .716 & .793 & .759 & & & & & & & & & & & & \\
\hline 17.636 & .401 & .511 & .539 & .549 & .498 & .545 & .583 & .723 & .646 & .606 & .702 & .666 & .728 & .636 & .713 & & & & & & & & & & & \\
\hline 18.564 & .316 & .412 & .427 & .464 & .398 & .471 & .473 & .648 & .583 & .494 & .594 & .590 & .654 & .563 & .619 & .735 & & & & & & & & & & \\
\hline 19.650 & .376 & .490 & .513 & .531 & .471 & .541 & .555 & .747 & .655 & .580 & .695 & .681 & .729 & .644 & .727 & .767 & .804 & & & & & & & & & \\
\hline 20.678 & .465 & .572 & .613 & .638 & .578 & .606 & .616 & .719 & .728 & .643 & .738 & .674 & .741 & .690 & .755 & .693 & .600 & .734 & & & & & & & & \\
\hline 21.630 & .347 & .459 & .488 & .502 & .449 & .530 & .529 & .759 & .654 & .561 & .700 & .680 & .754 & .623 & .715 & .710 & .682 & .783 & .700 & & & & & & & \\
\hline 22.488 & .214 & .329 & .338 & .362 & .314 & .427 & .405 & .614 & .487 & .379 & .540 & .557 & .594 & .511 & .564 & .608 & .597 & .685 & .573 & .741 & & & & & & \\
\hline 23.487 & .290 & .388 & .390 & .403 & .377 & .412 & .390 & .478 & .473 & .372 & .449 & .487 & .504 & .438 & .470 & .476 & .497 & .534 & .511 & .494 & .484 & & & & & \\
\hline 24.478 & .279 & .341 & .368 & .380 & .348 & .397 & .362 & .500 & .467 & .359 & .432 & .453 & .502 & .439 & .469 & .466 & .461 & .523 & .482 & .505 & .483 & .670 & & & & \\
\hline 25.497 & .338 & .380 & .419 & .420 & .385 & .429 & .419 & .519 & .526 & .406 & .484 & .488 & .511 & .475 & .510 & .548 & .555 & .603 & .532 & .546 & .524 & .586 & .623 & & & \\
\hline 26.481 & .290 & .389 & .393 & .378 & .338 & .387 & .399 & .512 & .466 & .380 & .465 & .512 & .512 & .443 & .487 & .559 & .535 & .579 & .494 & .545 & .538 & .608 & .641 & .683 & & \\
\hline 27.604 & .323 & .446 & .472 & .470 & .390 & .490 & .505 & .677 & .580 & .509 & .637 & .652 & .682 & .566 & .644 & .652 & .634 & .711 & .626 & .708 & .663 & .611 & .589 & .623 & .720 & \\
\hline 28.588 & .311 & .431 & .466 & .477 & .399 & .491 & .487 & 689 & .595 & .508 & .625 & .666 & .682 & .581 & .641 & .675 & .647 & .717 & .630 & .711 & .677 & .641 & .639 & .666 & .734 & .856 \\
\hline
\end{tabular}

Our results also support the use of the TSIHE over other instruments measuring teaching styles. Three important differences will be highlighted between TSIHE's contribution in relation to other similar instruments such as the Teaching Styles Questionnaire (TSQ) and the Teaching Styles Inventory (TSI).

First, the TSIHE, in comparison to the other instruments, possesses a properly estimated structure and high reliability indexes. The TSIHE clearly exceeds the TSQ's reliability indexes, but it is not possible to compare their factor structure as the structure adequacy of the TSQ has not been studied. In relation to the TSI, the TSIHE reliability indexes are higher than those of the TSI original version. Regarding the newly modified TSI version (Gafoor \& Babu, 2016), both questionnaires shows similar indexes, though it persists the methodological problem of using Cronbach's alpha with ipsative data.

The second difference between the three instruments relies on the theoretical support of their scales. The authors of the TSI and TSQ formulate the scales of these questionnaires as typologies derived from previous proposals of learning style questionnaires. The TSI emerges from the Grasha-Riechmann Student Learning Styles Scale (GRSLSS), and the TSQ emerges from the Honey-Alonso learning styles questionnaire (CHAEA). As previously, mentioned the construct of learning style is currently highly questioned (An \& Carr, 2017), particularly because of the lack of empirical evidence that demonstrates its actual influence on learning and achievement. The TSIHE moves away from these formulations by building the scales from students' perceptions. To create them, the Multiple item classification technique was employed as an interview technique. University students were individually asked to freely classify their teachers, generating and nominating their own categories. Using this technique, the TSIHE has a closer conceptual organization system to students' perceptions of teachers' actions. Additionally, the student's information is compared with real elements of the classroom teaching activity, which better represent the complexity of the classroom system (Abello \& Hernández, 2010).

The third difference has to do with the person responding to the instrument. The TSIHE is answered by students instead of teachers and, therefore, has not the inconveniences of self-report. As it is known, self-reports are biased by the vision teachers have of themselves and of their work in the classroom, rather than being based on their actual behav- 
iors, which are perceived and valued by the students. Having one version for students and one for teachers, the TSIHE is of great help in estimating the level of teachers' bias. Additionally, the TSIHE functions as a self-reflection instrument to inform about a teacher's professional practice.

This study has three main limitations. First, it only examines two of the three dimensions initially proposed by Abello et al. (2012) omitting the Classroom strategies dimension. This dimension is measured though force-choice items, generating ipsative data in the four scales of it, which hinders conducting joint studies with the scales analyzed here, unless scores are modified according with the methodology of Brown \& Maydeu-Olivares (2012). Second, the instrument's predictive validity has not been explored because of the lack of data about the teaching style influence on the student's learning processes. Third, the sample is compounded of preservice teachers, which might pose a limitation when applying the questionnaire to other degrees. In future research we will aim at exploring the validity of the ipsative data, cross-

\section{References}

Abello, D. \& Hernández, C. (2010). Diseño y validación de un modelo teórico e instrumental para la identificación de estilos de enseñanza en docentes universitarios Cdesign and validation of theoretical and intrumental model to identify the university professor's teaching style]. Tesis de maestría. Universidad Pedagógica Nacional. Bogotá. http:/ / repository.pedagogica.edu.co/bitstream/handle/20.500.12209/ 7798/TO-13140.pdf?sequence $=1$ \&isAllowed $=\mathrm{y}$

Abello, D., Hernández, C. \& Hederich, C. (2012). Características psicométricas del instrumento de estilos de enseñanza de Abello, Hernández y Hederich. [Psychometric characteristics from the Abello, Hernandez and Hederich teaching styles' instrument] En Estilos de aprendizaje: investigaciones y experiencias: [V Congreso Mundial de Estilos de Aprendizaje], Santander, 27, 28 y 29 de junio de 2012. https://www.researchgate.net

Alonso-Tapia, J. (1997). Motivar para el aprendizaje. Teoría y estrategias. Barcelona, España: Edebé.

Alonso-Tapia, J. \& Fernández-Heredia, B. (2009). Un modelo para el análisis del clima motivacional de clase: validez transcultural e implicaciones educativas. Infancia Y Aprendizaje, 32(4), 598-612.

Alonso, C., Gallego, D., \& Honey, P. (1994). Los estilos de aprendizaje: ¿Qué son? ¿Cómo diagnosticarlos? ¿Cómo mejorar el propio estilo de aprendizaje? Learning styles: What are they? How to asses them? How to improve one's learning style] Bilbao: Mensajero

An, D. \& Carr, M. (2017). Learning styles theory fails to explain learning and achievement: Recommendations for alternative approaches. Personality and Individual Differences, 116, 410-416. https://doi.org/10.1016/j.paid.2017.04.050

Antoniou, F. \& Kalinogloua, F. (2013). Teaching Style: Is it Measurable and Changeable? Procedia-Social and Behavioral Sciences, 93, 1618-1623. http://dx.doi.org/10.1016/j.sbspro.2013.10.090

Bandura, A. (1991). Self-regulation of motivation through anticipatory and self-reactive mechanisms. In Lincoln: University of Nebraska Press. (Ed.), Perspectives on motivation: Nebraska symposium on motivation (Vol. 38, pp. 69-164).

Bennett, N. (1979). Estilos de enseñanza y progreso de los alumnos. Madrid: Morata.

Bertalanffy, L. (1976). Teoría general de los sistemas [General systems theory]. Fondo de cultura económica, México.

Beyhan, Ö. (2018). Student Perceptions on the Teaching Styles of Their Teachers. H. U. Journal of Education. Advance online publication. http:/ /dx.doi.org/10.16986/HUJE.2018036946 validate the results from the model analyzed here against data from other already validate questionnaires creating more comprehensive models and amplify our sample covering other degrees and countries.

As a conclusion, this study has tested the TSIHE structural characteristics, proving that the instrument, and the theoretical model behind are supported by empirical data in terms of reliability and validity. The instrument shows superior psychometric qualities to similar instruments, presenting two additional positive aspects: not being based in learning approaches theory and the students are the respondents. This aspect is key as teachers could use the instrument in their classroom groups to identify how is theirs teaching style perceived, and make changes in their instructional approach accordingly.

Acknowledgments.- Third author funded by personal grant under Ramón y Cajal framewok (RYC-2013-13469).

Brown, A., \& Maydeu-Olivares, A. (2012, November 12). How IRT Can Solve Problems of Ipsative Data in Forced-Choice Questionnaires. Psychological Methods. Advance online publication. https://doi.org/10.1037/a0030641

Brostrom, R. (1975). Training Style Inventory. Developing Effective Teaching. COMCOR http://my.ilstu.edu/.../TRAINING\%20STYLE\%20IN... on 25.05.15

Camargo, A. (2010). Una mirada integral al estilo de enseñanza. [an integral look at the teaching style] Actualidades Pedagógicas, 55, 23-30. https://doi.org/10.19052/ap.878

Camargo, A. \& Hederich, C. (2007). El estilo de enseñanza. Un concepto en búsqueda de precisión. [The teaching style. Search for a precise concept] Pedagogía y Saberes, 26, 31-40. https://doi.org/10.17227/01212494.26pys31.40

Chan, W. (2003). Analyzing ipsative data in psychological research. Behaviormetrika, 30(1), 99-121. http://dx.doi.org/10.2333/bhmk.30.99

Chang, Y. C. (2010). Students' perceptions of teaching styles and use of learning strategies. Master thesis. University of Tennessee. http:/ / trace.tennessee.edu/utk_gradthes/782

Chiang, M. T., Diaz, C., Amer, R. \& Martínez-Geijo, P. (2013). Validación del cuestionario estilos de enseñanza (CEE). Un instrumento para el docente de educación superior. [Validation of learning styles questionnaire (EEC). an instrument for higher education teaching] Journal of Learning Styles, 6 (12), 1-16.

Covarrubias, P. \& Piña, M. (2004). La interacción maestro-alumno y su relación con el aprendizaje. [professors and students interaction and their influence on learning] Revista Latinoamericana de Estudios Educativos (México), 34(1), 47-84. www.redalyc.org/articulo.oa?id=27034103

Evans, C. (2004). Exploring the relationship between cognitive style and teaching style. Educational Psychology, 24(4), 509-530. https://doi.org/10.4324/9781315885438

Evans, I. M., Harvey, S. T., Buckley, L. \& Yan, E. (2009). Differentiating classroom climate concepts: Academic, management, and emotional environments. Kötuitui: New Zealand Journal of Social Sciences Online, 4(2), 131-146. https://doi.org/10.1080/1177083X.2009.9522449

Fischer, L. \& Fischer, B. (1968). Learning styles, teaching styles, and individualized instruction. In Hildebrand, Edwin Ed. Quality and the Small School. 30-34. URL: https://files.eric.ed.gov/fulltext/ED027107.pdf

Frunzâ, V. (2014). Implications of Teaching Styles on Learning Efficiency. Procedia-Social and Behavioral Sciences, 127, 342-346. https://doi.org/10.1016/j.sbspro.2014.03.268 
Gafoor, A. \& Babu, H. (2016). Development and Standardization of a Teaching Style Inventory among Secondary School Teachers of Kerala. Guru Journal of Behavioral and Social Sciences, 4 (1 y 2), 512-528. https://www.researchgate.net/publication/318054965_Teaching_Style A_Conceptual_Overview

Grasha, A. F. (1996). Teaching with style: A practical guide to enhancing learning by understanding teaching and learning styles. San Bernardino: Alliance.

Hair, J. F., Black, W. C., Babin, B. J., \& Anderson, R. E. (2010). Multivariate data analysis. Upper Saddle River, NJ: Pearson-Prentice Hall.

Henderson, K. H. (2016). The Effect of Higher Education Classroom Management Behavior Strategies on Learning. (Doctoral dissertation). Walden University, College of education. Minneapolis http://scholarworks.waldenu.edu/dissertations

Hernández, C. \& Abello, D. (2013). Los estilos de enseñanza de los docentes de la Licenciatura en Educación con Énfasis en Educación Especial de la Universidad Pedagógica Nacional. [Teaching styles of teachers in the Education Degree with Special Education Emphasis from the Universidad Pedagógica Nacional] Revista Colombiana de Educación, (64), 309-325.

Hersey, P. \& Blanchard, K.H. (1969). The life cycle theory of leadership. Training and Development Journal, 23 (5), 26-34. https://doi.org/10.4236/jss.2016.48016 1,277

Martínez, P. (2009). Estilos de enseñanza: Conceptualización e Investigación. (En función de los estilos de aprendizaje de Alonso, Gallego y Honey). [Teaching styles: conceptualization and investigation (according to the learning styles by Alonso, Gallego \& Honey)] Journal of Learning Styles, 2(3), 3-19. http://learningstyles.uvu.edu/index.php/jls/article/view/152/110

Muthén, L.K. \& Muthén, B.O. (1998-2012). Mplus. Statistical analysis with latent variables. Seventh edition. Los ángeles, CA: Muthén \& Muthén
Pajares, M.F. (1992). Teachers' beliefs and educational research: Cleaning up a messy construct. Review of educational research, 62(3), 307-332. https://doi.org/10.3102/00346543062003307

Panadero, E., \& Alonso-Tapia, J. (2014). How do students self-regulate? Review of Zimmerman's cyclical model of self-regulated learning. Anales De Psicología / Annals of Psychology, 30(2), 450-462. https://doi.org/10.6018/analesps.30.2.167221

Rendón, M. A. (2013). A Conceptualization of Teaching Styles. Revista Colombiana de Educación, (64), 175-195.

Renes, P., Echeverry, L. M., Chiang, M. T. \& Rangel, L. (2013). Estilos de enseñanza: un paso adelante en su conceptualización y diagnóstico. [learning styles: a step forward in its conceptualization and diagnosis.] Journal of Learning Styles, 6(11), 3-19. http://learningstyles.uvu.edu/index.php/jls/article/view/180/141

Rosenman, R., Tennekoon, V. \& Hill, L. G. (2011). Measuring bias in selfreported data. International Journal of Behavioural and Healthcare Research, 2(4), 320-332. https://doi.org/10.1504/IJBHR.2011.043414.

Simón, C. \& Alonso-Tapia, J. (2016). Clima positivo de gestión del aula: efectos del clima de gestión de la disrupción en el comportamiento y en la satisfacción con el profesorado. [Learning styles: a step forward in its conceptualization and diagnosis.] Revista de Psicodidáctica, 21(1). https://doi.org/10.1387/RevPsicodidact.13202

Sowell, H. K. (2013). Classroom management strategies: The impact on student achievement. (Doctoral dissertation). Liberty University, Lynchburg Virginia. http://www.proquest.com

Zimmerman, B. J. (2000). Attaining self-regulation: A social cognitive perspective. In Boekaerts, M., Zeidner, M. \& Pintrich, P. R. Handbook of self-regulation (pp. 13-39). Academic Press. 


\section{Appendix 1. Teaching Styles Inventory for Higher Education}

Scale 1: Teacher-student interaction

1. Acts as a mediator when a conflict exists between students.

2. Students can approach to share their personal problems.

3. Identifies the group's emotional environment, considering it in the development of the course.

4. Manifests interest in students' wellbeing beyond the academic context.

5. Shows interest in getting to know and bonding with students.

6. Has a close relationship with students.

7. Recognizes individualities within the group.

8. Generates a socialization space before beginning the class.

9. Greets the students outside the classroom

10. Is concerned for students' individual progress.

Scale 2: Decision-making Negotiation

11. Is flexible with the activities proposed in the syllabus.

12. Prefers to reach agreements rather than impose decisions.

13. In consensus with the students, the classroom rules are set (schedule, recess, use of mobile telephones...).

14. Faced with unforeseen situations, the teacher agrees with students the actions to be followed.

15. Adjusts course subject matters to the group's interests and needs.

16. Listens and considers the student's reasons when they make a mistake.

Scale 3: Teaching structuring

17. Begins the class session by presenting the activities that will be developed.

18. Carries out clearly established routines during the class session.

19. Develops the curse following a clear structure.

20. Provides feedback on students' performance throughout the semester.

21. Makes the assessments described in the syllabus.

22. Is strict with work delivery times.

Scale 4: Behavioral control

23. Pays constant attention to all bad behaviour

24. Confronts students when they exhibit an inappropriate behaviour

25. Constantly controls and monitors that the student fulfils the designated role for the class

26. Generates corrective actions when they see that one or several students are not paying attention

27. Ensures there is silence when they or a student is talking

28. Demands, from their students, appropriate behaviour during course 


\section{Apéndice 2. Inventario de Estilos de Enseñanza para Educación Superior}

\section{Escala 1: Interacción profesor-alumno}

1. Actúa como mediador cuando existe un conflicto entre los estudiantes

2. Los estudiantes pueden acercarse para compartir sus problemas personales

3. Identifica el ambiente emocional de grupo teniéndolo en cuenta para el desarrollo de la clase

4. Manifiesta interés por el bienestar de los estudiantes más allá del contexto académico

5. Muestra interés por conocer y vincularse con los estudiantes

6. Se relaciona con los estudiantes de manera cercana

7. Reconoce las individualidades dentro del grupo

8. Genera un espacio de socialización antes de iniciar la clase

9. Saluda a los estudiantes fuera de la clase

10. Se preocupa por el progreso individual de los estudiantes

\section{Escala 2: Negociación para tomar decisiones}

11. Es flexible con las actividades propuestas en el programa

12. Prefiere llegar a acuerdos que imponer decisiones

13. En consenso con los estudiantes se plantean las normas de la clase (hora de ingreso, receso, uso del celular...)

14. Frente a situaciones imprevistas, el docente acuerda con los estudiantes las acciones a seguir

15. Adapta las temáticas de la clase a los intereses y necesidades particulares del grupo

16. Escucha y toma en cuenta las razones del estudiante cuando se equivoca

\section{Escala 3: Estructuración de la enseñanza}

17. Introduce la clase enunciando las actividades que se desarrollaran

18. Lleva a cabo rutinas claramente establecidas durante la sesión de clase

19. Desarrolla la clase siguiendo una estructura clara

20. Retroalimenta el desempeño de los estudiantes a lo largo del semestre

21. Realiza las evaluaciones planteadas en el programa

22. Es estricto con las fechas de entrega de trabajos

\section{Escala 4: Control del comportamiento}

23. Presta atención constante a todo "mal comportamiento"

24. Confronta al estudiante cuando este exhibe un comportamiento no adecuado

25. Controla y monitorea constantemente que el estudiante cumpla el rol designado para la clase

26. Genera correctivos cuando ve que uno o varios estudiantes no están prestando atención

27. Se asegura de que haya silencio cuando él o uno de los estudiantes está interviniendo

28. Exige de sus estudiantes un "comportamiento adecuado durante la clase" 